\title{
Aprendizagem e Desenvolvimento de Crianças de Seis Anos na Roda de História
}

\author{
Tatyane Andrade Almeida' \\ Maria de Fátima Cardoso Gomes' \\ Sara Mourão Monteiro' \\ 'Universidade Federal de Minas Gerais (UFMG), Belo Horizonte/MG - Brasil
}

RESUMO - Aprendizagem e Desenvolvimento de Crianças de Seis Anos na Roda de História. Este artigo visa compreender como a leitura oral dos livros de literatura infantil feita pela professora pode contribuir para a aprendizagem da leitura e para o desenvolvimento mental e cultural dos alunos de seis anos. Para tanto, analisamos as interações discursivas entre crianças e professora de uma sala de aula de primeiro ano do Ensino Fundamental em que essa prática de leitura foi construída destacando como os sentidos da leitura, os conhecimentos de mundo e as identidades dos sujeitos vão sendo construídos coletivamente no processo discursivo e nas interações em sala de aula. Concluímos que o trabalho com a literatura em sala de aula deve proporcionar a construção coletiva e individual de sentidos.

Palavras-chave: Crianças. Roda de História. Aprendizagem. Desenvolvimento.

\begin{abstract}
Learning and Development of Six Year Old Children During Story Time. In this paper we aim to analyze how oral reading of children's books made by the teacher can contribute to literacy learning and to mental and cultural development of six year old students. In order to do that, we analyze discursive interactions between children and teacher in a First Grade classroom. In this classroom, reading practice was build stressing how the reading meaning, the knowledge of the world and the participant's identities are collectively constructed in the discursive process and in the classroom interactions. We conclude that the work with literature in classroom should provide the construction of collective and individual senses. Keywords: Children. Story Time. Learning. Development.
\end{abstract}

Educação \& Realidade, Porto Alegre, v. 38, n. 4, p. 1303-1326, out./dez. 2013. 1303 Disponível em: <http://www.ufrgs.br/edu_realidade> 


\title{
Literatura Infantil e Mediações Semióticas na Formação de Pequenos Leitores
}

Apoiados/as na perspectiva do letramento, os/as professores/as têm se empenhado em levar a leitura literária para suas práticas docentes de forma a apresentar às crianças a grande variedade de gêneros, temas e suportes que compõem o universo da literatura infantil. Nesse sentido, as escolhas do/a professor/a devem levar em conta não apenas a multiplicidade de textos que existe em nossa sociedade, mas também as possibilidades de aprendizagem que cada texto pode oferecer (Paiva; Rodrigues, 2008).

Entre os diferentes suportes em que a literatura infantil circula nas salas de aula, como por exemplo, o livro didático de Língua Portuguesa, as folhas mimeografadas ou xerocadas, o quadro de giz, entre outros, destaca-se o livro de literatura infantil.

\begin{abstract}
A interação com o livro é necessária ao letramento literário que envolve o conhecimento das características materiais do objeto, aspectos paratextuais que remetem à autoria, à editora, ao projeto gráfico que institui o diálogo entre as imagens e o texto verbal, enfim, a uma série de aspectos passíveis de serem experimentados somente com o contato direto com o livro (Paiva; Rodrigues, 2008, p. 111).
\end{abstract}

Uma das formas de interação com os livros presente nas escolas éa leitura em voz alta feita pelos/as professores/as. Para José Morais (1996), a audição de livros é o primeiro passo para a leitura, pois, além de tornar visível um conjunto variado de relações entre a linguagem escrita e a linguagem falada, fornece às crianças acesso a modelos e mecanismos de leitura essenciais na formação do leitor. Mas para que essa prática pedagógica possa contribuir efetivamente para formação das crianças nos anos iniciais do ensino fundamental é necessário que, ao planejar as atividades de leitura na sala de aula, o/a professor/a esteja atento/a a três componentes da prática de leitura para crianças. O primeiro deles diz respeito à escolha das obras, que devem propiciar a fruição estética, por meio de sua qualidade textual e gráfica. Os livros de literatura infantil devem favorecer a ampliação da vivência infantil e apresentar um equilíbrio entre texto, imagem e intervenções gráficas que levam o leitor à interpretação e reflexão do texto. O segundo componente está relacionado à organização do trabalho pedagógico. A leitura de textos literários deve fazer parte da rotina das ações junto às crianças, e não ser vista apenas como uma atividade para os intervalos entre atividades de ensino-aprendizagem. Os comportamentos de leitura constituem o último componente da prática de leitura de textos literários no espaço escolar. A apropriação da cultura letrada é resultado do convívio com pessoas letradas em situações de leitura e escrita - eventos de letramento. Segundo Monteiro e Baptista (2009),

1304 Educação \& Realidade, Porto Alegre, v. 38, n. 4, p. 1303-1326, out./dez. 2013. Disponível em: <http://www.ufrgs.br/edu_realidade> 
As crianças precisam ter oportunidades de observar e reelaborar suas representações sobre o "para que" e "como" as pessoas leem e escrevem em suas atividades diárias. Para isso, é importante que a ação pedagógica promova a participação das crianças em práticas autênticas de leitura e de escrita, no cotidiano da sala de aula, nas quais elas possam sempre interagir com esse objeto do conhecimento (Monteiro; Baptista, 2009, p. 40).

Estamos nos referindo, então, a uma prática social de leitura que articule significados socialmente construídos com sentidos e significações pessoais, sabendo que esse pessoal foi e é socialmente constituído. Foi, pois, pela mediação de signos (linguagem escrita, oral, ilustrações etc.) que as significações das crianças e professora acerca das práticas sociais de leitura constituíram-se e foram constituídas.

Ao analisarmos os registros produzidos por um estudo longitudinal e etnográfico de uma sala de aula de alfabetização de crianças, foi possível observar como esses componentes estão presentes em sala de aula. A aula aqui analisada é parte do material empírico produzido na pesquisa Incluindo Diferentes Alunos nas Salas de Aulas de Alfabetização de Crianças e Adultos: semelhanças e diferenças, em que foram pesquisadas duas salas de aula ${ }^{1}$, uma de crianças e outra de jovens e adultos, que, no ano de 2006, iniciaram o processo de alfabetização. Durante o processo de coleta de dados, com duração de três anos (2006 a 2008), foram feitas gravações em vídeo de aulas; análise de artefatos; anotações de campo; entrevistas com alunos e professoras; e reuniões com professoras e pais de alunos. Apoiada na abordagem histórico-cultural, no conceito de prática discursivamente construída e no conceito de relação com o saber, a pesquisa acima intitulada buscou compreender como, para que, com quem, quando, sob quais condições, com que resultados se ensina a língua escrita para crianças e adultos, além de contrastar as práticas de alfabetização entre duas salas de aula de alfabetização: crianças e adultos (Gomes, 2005; Dias, 2011).

Entretanto, neste trabalho analisaremos apenas as práticas de leitura da sala de aula de crianças. Mais especificamente, analisaremos a atividade denominada Roda de História, em que a professora da sala de aula pesquisada lê livros literários para os alunos. Nosso intuito é observar como essa prática se constituiu e quais as oportunidades de aprendizagem e de desenvolvimento dos alunos que ela possibilitou. Para tanto, selecionamos uma aula do ano de 2006 em que essa atividade foi trabalhada pela professora.

Na sala de aula pesquisada, as crianças tinham pelo menos um horário durante a semana destinado à leitura de livros pela professora. Os exemplares eram escolhidos pela professora ou pelas crianças, e faziam parte de acervos pessoais ou da instituição. Os alunos poderiam trazer de casa um livro para ser lido na roda; a única condição era a avaliação prévia do exemplar pela professora (Dias, 2011).

Educação \& Realidade, Porto Alegre, v. 38, n. 4, p. 1303-1326, out./dez. 2013.1305 Disponível em: <http://www.ufrgs.br/edu_realidade> 
Aprendizagem e Desenvolvimento de Crianças de Seis Anos na Roda de História

Na sala de aula os alunos eram organizados em grupos de quatro e, às vezes, em duplas. Diariamente, os membros desse grupo seguiam uma rotina previamente estabelecida e nomeada pela professora. Contudo, essa estrutura não se configurou como algo rígido, pequenas mudanças ocorreram por iniciativa da professora ou devido à demanda da turma. Em geral, faziam parte do trabalho diário: chegada, livro, arquivo poético, hora de escrever, leitura, biblioteca da escola, roda de história, biblioteca da sala, hora do brinquedo, recreio, roda de conversa e desenho. A mesma professora acompanhou a turma durante os três anos para dar continuidade ao seu trabalho (Gomes, 2005; Dias, 2011).

A atividade Roda de História foi trabalhada pela professora ao longo dos três anos em que esteve com a turma e que correspondem também aos anos de realização da pesquisa, porém optamos trabalhar apenas com os dados do ano de 2006, na sala das crianças, para a elaboração deste texto. Com base nos mapas de eventos e nas transcrições em sequências discursivas, produzidos a partir do material empírico coletado em sala de aula, selecionamos, para compor nossa análise, a aula do dia 11 de abril de 2006 em que a atividade fez parte da rotina diária. Para orientar nossas análises levantamos as seguintes perguntas: como, para que, com quem, quando, sob quais condições e com que resultados se lê o texto literário na sala de aula.

\section{Pressupostos Teórico-Metodológicos}

A participação da primeira autora na pesquisa começou no ano de 2010, etapa em que a coleta de dados já havia terminado e os mapas de eventos e transcrições das Sequências Discursivas em Message Units (ou Unidades de Mensagem) das aulas gravadas em vídeo estavam sendo elaborados. Segundo o Grupo de Pesquisa e Discurso de Sala de Aula de Santa Barbara, "[...] evento é o produto das interações entre participantes, é uma forma de estabelecer as fronteiras de atividades colaborativas envolvidas no processo de ensino-aprendizagem" (Gomes, 2005, p. 4). Os eventos ocorridos em uma sala de aula são construídos e sinalizados pelas ações dos atores e das interações e são historicamente influenciados pelos eventos que o precederam, naquele dia ou em dias anteriores.

Dessa forma, o mapa de eventos nos permite mostrar o tempo gasto em sala de aula e as fases das atividades, os tópicos que estão sendo discutidos, bem como os papéis e as relações que estão sendo estabelecidas, ou seja, os padrões de interação construídos pelos membros do grupo (Gomes, 2005).

A partir da análise dos mapas de eventos, foram escolhidas as aulas a serem transcritas na íntegra, em unidades de mensagem. A transcrição evidencia quem está falando, como está falando, para quem, com quem e em quais situações de ensino aprendizagem, permitindo uma atitude de investigação mais profunda das interações estabelecidas entre os participantes da sala de aula. Essa transcrição, por sua vez, não é

1306 Educação \& Realidade, Porto Alegre, v. 38, n. 4, p. 1303-1326, out./dez. 2013. Disponível em: <http://www.ufrgs.br/edu_realidade> 
neutra, ela reflete objetivos e definições teóricas, segundo nos diz Green, Franquiz, Dixon (1999):

\begin{abstract}
$\mathrm{O}$ ato de escolher um segmento da vida da sala de aula para transcrever implica tomar decisões sobre a importância do pedaço da fala ou do evento, que, por sua vez, implica que a fala ou o evento seja interpretado de algum ponto de vista (...). A escolha de uma unidade de fala para transcrever é um ato político (...). Então, escrever o que se ouve de alguém falando é o resultado de uma cadeia de atos interpretativos (Green; Franquiz; Dixon, 1999, p.173² citado por Gomes, 2005, p. 5).
\end{abstract}

A Unidade de Mensagem, por sua vez, é a menor unidade de significação conversacional produzida pelos falantes, sendo definida em termos de sua origem e forma, seu propósito e nível de compreensão e das ligações entre elas. A fronteira de uma unidade de mensagem é linguisticamente marcada pelas pistas de contextualização, que podem ser: verbais (entonação, pausas, cortes de fala), não-verbais (gestos, expressões faciais, mímicas) e pistas co-verbais (prosódicas) que podem definir uma mensagem ou um evento que se quer analisar. Em uma sequência discursiva as unidades de mensagem são apresentadas em linhas numeradas, facilitando a identificação e análise.

Entendemos, então, que é no processo discursivo que os eventos são criados e neles os sentidos e significações para a aprendizagem da leitura e da escrita são construídos assim como as identidades dos sujeitos da pesquisa. Pois, é no contexto da interlocução, vista aqui como processo social de produção de significação (Pino, 1991), que os sujeitos são construídos, assim como a sala de aula. Desse ponto de vista, as salas de aula são vistas como culturas e são construídas socialmente por professores e estudantes nas relações com contextos institucionais e culturais (Gomes, 2005).

Assistindo às gravações para elaboração dos mapas de eventos e das transcrições em sequências discursivas, pudemos observar detalhadamente o que aconteceu na sala de aula das crianças. Dessa forma, tendo nos interessado especialmente pelos momentos de Roda de História na sala de aula de crianças, selecionamos, inicialmente, três aulas do ano de 2006 em que a atividade foi trabalhada, para compor o corpus de análise deste trabalho.

Entretanto, devido às limitações desse texto, será analisada, aqui, apenas a aula do dia 11 de abril de 2006, buscando destacar, num primeiro momento, as estratégias utilizadas pela professora na realização da leitura em partes, já que a leitura do livro O Menino Maluquinho, de Ziraldo, havia sido iniciada em uma aula anterior e estava sendo retomada nesta aula; posteriormente, destacaremos as oportunidades de aprendizagem e de desenvolvimento mental e cultural presentes na prática de leitura oral feita pela professora.

Educação \& Realidade, Porto Alegre, v. 38, n. 4, p. 1303-1326, out./dez. 2013.1307 Disponível em: <http://www.ufrgs.br/edu_realidade> 
Aprendizagem e Desenvolvimento de Crianças de Seis Anos na Roda de História

É importante ressaltar que a escolha desses momentos para a elaboração deste trabalho também foi influenciada pela participação da primeira autora no projeto de extensão Leitura Literária para Crianças Pequenas. Esse projeto ${ }^{3}$ tem por objetivo aprofundar conhecimentos sobre a prática de leitura mediada e a escuta de textos por crianças pequenas e suas implicações no processo de formação do leitor.

\section{Sujeitos da Pesquisa}

As crianças que participaram da pesquisa Incluindo diferentes alunos nas salas de aula de alfabetização ingressaram no Centro Pedagógico da UFMG (CP), no primeiro ano, em 2006, e fizeram parte da implantação inicial do ensino fundamental de nove anos na escola. Dessa forma, foi a primeira vez que o corpo docente recebeu crianças de cinco anos e meio e seis anos. Na turma pesquisada, denominada pelos alunos e professora de primeiro ano do Abraço, havia 24 estudantes matriculados, 12 estudantes do sexo masculino e também 12 estudantes do sexo feminino. É importante acrescentar que todos os alunos frequentaram anteriormente uma instituição de educação infantil (pública ou particular), por isso muitos já haviam sido alfabetizados (Dias, 2011).

A professora Luciana ${ }^{4}$ tinha 42 anos, graduou-se em Pedagogia pela Universidade Federal de Minas Gerais no final da década de 1990. Concluiu o Mestrado em Educação na mesma instituição em 2003. Começou a trabalhar no CP no ano de 2006, após aprovação em concurso público. Dessa forma, alunos e professora estavam iniciando os seus percursos nessa escola. Contudo, Luciana tinha bastante experiência no trabalho com o ensino fundamental, pois havia atuado anteriormente como professora da rede pública estadual em Itabirito, sua cidade de origem (Dias, 2011).

\section{Resultados \\ Análises das Atividades de Roda de História Aula do Dia 11 de abril de 2006}

$\mathrm{Na}$ aula desse dia, os alunos e a professora chegaram à sala e organizaram as carteiras que estavam enfileiradas em grupos de quatro, disposição normalmente utilizada por Luciana em suas aulas, durante o ano. Em seguida, a professora deu início à construção e registro da Rotina do Dia, evento realizado diariamente pelo grupo e que consiste na listagem das atividades a serem realizadas pelo grupo ao longo do dia. Nessa aula, a Rotina do Dia foi elaborada da seguinte forma: Chegada, Arquivo Poético, Roda de História, Hora de escrever, Para casa, Tópicos Integrados (T.I), Merenda, Recreio, T.I, Saída. Após conferir a chegada, o que resultou em um novo momento de organização da sala de aula (com a professora pedindo aos alunos que observassem seus materiais), a professora deu início ao Arquivo Poético. Nessa atividade, foram reci-

1308 Educação \& Realidade, Porto Alegre, v. 38, n. 4, p. 1303-1326, out./dez. 2013

Disponível em: <http://www.ufrgs.br/edu_realidade> 
tadas as poesias que já faziam parte do arquivo dos alunos (Mistério de Amor, de José Paulo Paes, e A Casa, de Vinícius de Morais) e introduziuse uma nova poesia para composição do acervo: As Borboletas, também de Vinícius de Morais.

Em seguida, a professora anunciou a Roda de História, pedindo aos alunos para se sentarem ao fundo da sala para ouvirem a história. Novamente, tem-se um momento de reorganização da sala de aula, em que alunos e professora se preparam para realizar a atividade. Luciana dá início à leitura do livro O Menino Maluquinho, de Ziraldo, para os alunos.

No Quadro 1, abaixo, apresentamos a síntese do mapa de eventos elaborado a partir da aula em questão. Na primeira coluna tem-se o início de cada evento, de acordo com o tempo da gravação; na segunda coluna estão os eventos categorizados, destacando as atividades desenvolvidas; e na terceira coluna a duração aproximada de cada evento.

Quadro 1 - Síntese do Mapa de Eventos

\begin{tabular}{|l|l|l|}
\hline Tempo & Eventos & Duração (aprox.) \\
\hline 00:00 & Chegada dos alunos e da professora. & 05 minutos \\
\hline $05: 00$ & Organização da sala de aula. & 09 minutos \\
\hline $14: 03$ & Orientação dada pela professora aos alunos. & 02 minutos \\
\hline $15: 57$ & Atividade: elaboração da Rotina do dia. & 07 minutos \\
\hline $22: 36$ & Organização da sala de aula. & 02 minutos \\
\hline $24: 48$ & Atividade: Arquivo Poético & 09 minutos \\
\hline $33: 52$ & Organização da sala de aula. & 03 minutos \\
\hline $36: 35$ & Atividade: Roda de história & 21 minutos \\
\hline $57: 57$ & Organização da sala de aula. & 03 minutos \\
\hline $01: 00: 40$ & Atividade de Escrita. & 26 minutos \\
\hline $01: 26: 05$ & Organização da sala de aula. & 46 segundos \\
\hline $01: 26: 51$ & Fim da gravação. & \\
\hline
\end{tabular}

Para facilitar a análise, apresentaremos, ao longo do texto, alguns quadros que descrevem detalhadamente o evento Roda de História, e que poderão ser identificados pelas legendas: Quadro 2A, Quadro 2B, Quadro 2C, Quadro 2D e Quadro 2E. Além destes, traremos também outros quadros com trechos das sequências discursivas produzidas pelos participantes do grupo, destacando algumas interações relevantes para o nosso estudo. Estes quadros poderão ser identificados pelas legendas: Quadro 3A, Quadro 3B, Quadro 3C, Quadro 3D e Quadro 3E. Optamos por utilizar este recurso metodológico a fim de situar melhor o leitor no contexto da sala de aula e, mais precisamente, da atividade analisada.

\section{Roda de História: O Menino Maluquinho}

O livro nos conta a infância de um menino esperto, sabido, alegre e muito travesso, mas, acima de tudo, um menino feliz. Curte sua infância inventando brincadeiras, fazendo versinhos, contagiando todo

Educação \& Realidade, Porto Alegre, v. 38, n. 4, p. 1303-1326, out./dez. 2013. 1309 Disponível em: <http://www.ufrgs.br/edu_realidade> 
mundo com sua alegria e entusiasmo. Com seus versos e ilustrações, Ziraldo compõe uma obra que retrata a infância de muitas crianças, marcada por aventuras e também por conflitos. A obra, escrita em 1980, recebeu no ano seguinte o prêmio Jabuti de Literatura, principal premiação voltada para a literatura infantil.

Publicado pela editora Melhoramentos, o livro é indicado para leitores em processo, a partir dos oito anos de idade. Essa indicação, no entanto, não impede que crianças menores tenham acesso à obra, seja através da leitura mediada por um adulto ou leitor mais experiente, seja através de suas ilustrações e projeto gráfico. Porém, em razão de sua extensão (112 páginas), torna-se necessário que a leitura do livro para crianças menores se dê em partes.

Em geral, alguns argumentos são apresentados para se evitar esse tipo de prática na escola, como por exemplo, a capacidade de memória das crianças pequenas. Dessa forma, são escolhidos textos menores e mais fáceis, com muitas ilustrações. Porém, é importante notar que o trabalho com a criança pequena é marcado antes pela curta duração de sua atenção, o que inviabilizaria a realização de atividades extensas, como por exemplo, a leitura do livro inteiro, do que uma diminuta capacidade de memória. Ao contrário, as crianças tendem a memorizar tudo com mais facilidade, quando se faz uso de diferentes mediadores semióticos, o que se evidencia na participação ativa dos alunos no reconto da história e na leitura da história em partes. Além disso, é importante que as crianças tenham acesso a esse tipo de prática de leitura, essencial na formação do leitor hábil, capaz de ler textos maiores, como romances, já que raramente lemos um romance inteiro de uma só vez.

A escolha do livro O Menino Maluquinho por Luciana é, então, extremamente acertada, mesmo quando pensamos na idade de seus alunos: seis anos. Ao longo desse texto, veremos como o livro escolhido relaciona-se à infância, permitindo aos alunos se identificarem afetivamente com a leitura, instigando-lhes a curiosidade e contribuindo para seu desenvolvimento. A leitura de textos em parte, dividida em mais de uma aula, era comum na prática de Luciana, que, dessa forma, "não deixava de ler uma obra de qualidade em razão de sua extensão" (Dias, 2011, p. 173). Vejamos, no quadro 2A abaixo, como a professora Luciana deu início à leitura do livro para as crianças:

\section{Quadro 2A - Síntese descritiva da Roda de História}

\begin{tabular}{|l|l|}
\hline Linhas & Descrição das interações entre os participantes \\
\hline $1565-1584$ & $\begin{array}{l}\text { A professora encerra a atividade anterior, Arquivo Poético, e anuncia } \\
\text { a próxima atividade, Roda de História. Pergunta aos alunos com } \\
\text { qual história estão trabalhando. Chama a atenção dos alunos para } \\
\text { o que irá dizer. }\end{array}$ \\
\hline $1585-1630$ & $\begin{array}{l}\text { A professora pede aos alunos para se sentarem ao fundo da sala, não } \\
\text { sendo necessário sentar em roda, e diz que ficará em pé. }\end{array}$ \\
\hline
\end{tabular}

1310 Educação \& Realidade, Porto Alegre, v. 38, n. 4, p. 1303-1326, out./dez. 2013 Disponível em: <http://www.ufrgs.br/edu_realidade> 


\begin{tabular}{|l|l|}
\hline $1631-1701$ & $\begin{array}{l}\text { Os alunos abraçam Luciana. A professora insiste para que os alunos se } \\
\text { sentem no fundo da sala. Eles não obedecem prontamente e Luciana } \\
\text { diz que irá ficar brava com eles. }\end{array}$ \\
\hline $1702-1756$ & $\begin{array}{l}\text { A maioria dos alunos senta-se no chão e a professora começa a } \\
\text { organizá-los, indicando como eles devem se sentar, para onde devem } \\
\text { estar virados. Luciana senta-se em uma cadeira, próxima aos alunos. }\end{array}$ \\
\hline
\end{tabular}

No primeiro momento descrito no Quadro 2A (linhas 1565-1584), Luciana avisa que farão a Roda de História.

Nesse momento, a professora Luciana está organizando o espaço de leitura do livro, que pressupõe outra configuração da sala de aula. Para Paiva e Rodrigues (2008),

\begin{abstract}
A leitura de livros de literatura pode também instituir novos modos de ler na escola. Por ser um objeto de fácil locomoção, o espaço em que acontece a leitura não precisa ser necessariamente a carteira da sala de aula. Os alunos podem ser convidados a se sentarem no chão, em roda, para ficarem mais à vontade. Nesse momento, um clima de descontração é criado e a leitura literária se aproxima da leitura por prazer, por, de certa forma, sugerir protocolos de uma relação mais livre com a leitura (Paiva; Rodrigues, 2008, p. 112-114).
\end{abstract}

Essa relação mais livre com a leitura convida à participação dos ouvintes, abrindo espaço para a multiplicidade de interpretações e sentidos, aspecto fundamental da leitura literária, mas que, por sua vez, não exclui a necessidade dos comportamentos adequados às práticas de leitura. Assim, quando as crianças abraçam Luciana e resistem à indicação de se sentarem (Quadro 2A; linhas 1631-1701), é necessário que a professora assuma uma postura mais rígida, exigindo dos alunos tais comportamentos e questionando: "como que eu vou/ contar história/ com todo mundo/ abraçado comigo?” (Quadro 3A, linhas 1637-1640).

O momento de organização da roda pela professora pode ser melhor observado a partir das sequências discursivas produzidas pelos participantes nas interações, como nos mostra o Quadro 3A, a seguir:

Quadro 3A - Transcrição em sequência discursiva (Linhas 16141623 [...]; 1626-1646 [...]; 1666-1675 [...]; 1680-1696 [...]; 1702-1738)

\begin{tabular}{|c|c|c|}
\hline Linhas & Participantes & Comentários \\
\hline $\begin{array}{l}1614-1617 \\
1618-1620 \\
1621-1622 \\
1623\end{array}$ & $\begin{array}{l}\text { Profa.: nós vamos/ fazer/ uma roda/ de história } \\
\text { aqui/ nesse cantinho/ ó } \\
\text { só que eu vou/ ficar de pé } \\
\text { Alunos: não }\end{array}$ & $\begin{array}{l}\text { Luciana indica o } \\
\text { fundo da sala, en- } \\
\text { caminhando-se ao } \\
\text { local. Os alunos se } \\
\text { levantam. Alguns } \\
\text { encaminham-se } \\
\text { para o local indi- } \\
\text { cado. Outros abra- } \\
\text { çam a professora. }\end{array}$ \\
\hline
\end{tabular}

Educação \& Realidade, Porto Alegre, v. 38, n. 4, p. 1303-1326, out./dez. 2013. 1311 Disponível em: <http://www.ufrgs.br/edu_realidade> 


\begin{tabular}{|l|l|l|}
\hline $1626-1627$ & Profa: podem assentar/ lá & \\
$1628-1630$ & não precisa sentar/ em rodinha/ não & \\
1631 & vamo gente? & \\
$1632-1633$ & sentar/ lá & \\
$1634-1636$ & então/ eu não vou/ contar história & \\
$1637-1638$ & como que eu vou/ contar história & \\
$1639-1640$ & com todo mundo/ abraçado comigo? & \\
$1641-1642$ & vocês/ não vão ver & \\
$1643-1644$ & eu mostrar/ a ilustração & \\
$1645-1646$ & não vão ver/ nada & \\
1666 & & \\
$1667-1668$ & gente? & \\
$1669-1672$ & abraçado/ comigo & \\
$1673-1675$ & eũ̃o VOU/ é hora/ de abraçar/ a contar/ história & \\
$1680-1681$ & quer ver/ eu ficar brava & \\
$1693-1696$ & agora é hora/ de sentar/ pra contar/ história & \\
$1702-1703$ & senta aqui/ Igor & Luciana organiza \\
$1704-1705$ & virado/ pra cá & os alunos na Roda. \\
$1706-1708$ & ô::/ Fernanda/ e Sarah & Neste moment \\
$1709-1711$ & virado/ pra cá/ Igor & não há imagem da \\
$1712-1713$ & senta de jeito/ que você dá conta & professora, pois a \\
$1714-1717$ & de ficar/ a história/ toda/ assim & câmera está vol- \\
1718 & tá bom? & tada para a aluna \\
$1719-1720$ & não vai ficar/ levantando & Maria Eduarda que \\
$1721-1724$ & enem/ incomodando/ o colega/ não & permanece senta- \\
$1725-1726$ & isso vale/ pra todo mundo & da em seu lugar, \\
$1727-1728$ & viu/ moçada? & separada dogrupo. \\
$1729-1731$ & não é só/ pro Igor/ não & \\
$1732-1734$ & Karol/ Fernanda/ e Ana Carolina & \\
$1735-1736$ & arreda/ mais pra cá & \\
$1737-1738$ & fica mais juntinho/ aqui & \\
& & \\
\hline
\end{tabular}

Quando os alunos finalmente se assentam, Luciana os ajuda a se organizarem, dizendo para alguns deles nominalmente para onde devem estar virados e para acharem uma posição confortável (Quadro 3A; linhas 1702-1738). Luciana senta-se em uma cadeira, próxima aos alunos que não estão organizados em roda, mas em uma espécie de meialua, voltados para a professora. Embora a grande maioria esteja atenta à professora, alguns alunos brincam ou conversam, situação que irá requerer a intervenção de Luciana várias vezes durante o evento.

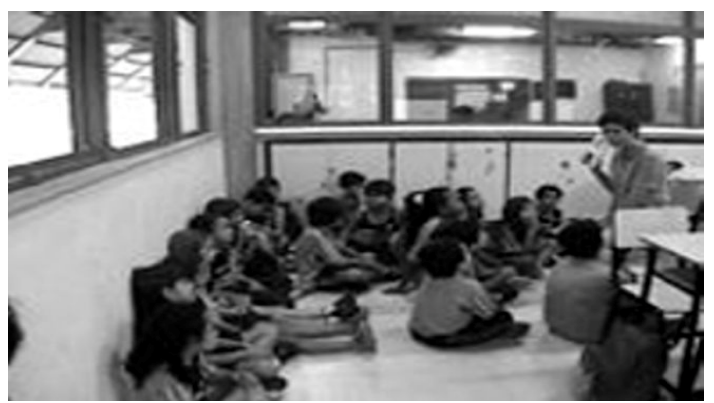

A dificuldade encontrada pela professora para organizar a roda indica que essa mudança de configuração precisa ser construída junto

1312 Educação \& Realidade, Porto Alegre, v. 38, n. 4, p. 1303-1326, out./dez. 2013. Disponível em: <http://www.ufrgs.br/edu_realidade> 
aos alunos. Vale lembrar que a aula analisada é de uma turma de primeiro ano do Ensino Fundamental e aconteceu ainda no início do ano escolar. Podemos inferir, então, que os alunos ainda não estavam habituados à forma de organização dessa atividade. Observa-se, ainda, a necessidade de uma série de comportamentos adequados para ouvir a história (fazer silêncio, sentar sem incomodar os outros e de maneira que todos possam ver a professora etc.), mediadores semióticos que vão sendo, dessa forma, apresentados pela professora e construídos junto às crianças que estão aprendendo a ser alunos, mais especificamente, a ser alunos que ouvem uma história e devem produzir sentidos e significações para esta atividade escolar.

Segundo Vigotski (1934-1993), é fundamental no processo de ensino-aprendizagem a utilização de mediadores semióticos que já estão à nossa disposição em nossas culturas, como também a construção coletiva e individual dos mesmos criando-se assim as possibilidades de Zonas de Desenvolvimento Iminentes (Prestes, 2010) que podem levar as crianças à produção de significados e sentidos do que se lê, para quê se lê, com quem, quando, com que objetivos e resultados.

O evento Roda de História, que envolve o aprender a ser aluno e ouvir e compreender os sentidos de uma história continua a ser construído por alunos e professora como se vê nos quadros 2B e 3B a seguir:

Quadro 2B - Síntese Descritiva da Roda de História

\begin{tabular}{|l|l|}
\hline Linhas & Descrição das interações entre os participantes \\
\hline $1757-1776$ & $\begin{array}{l}\text { Após a organização da roda, a professora relembra aos alunos } \\
\text { que a leitura do livro fora iniciada na semana anterior. Apresenta } \\
\text { novamente o livro e fala o nome do autor, o que não havia sido feito } \\
\text { anteriormente. }\end{array}$ \\
\hline $1777-1816$ & $\begin{array}{l}\text { João Pedro pergunta à professora como o autor consegue escrever } \\
\text { tantas páginas, interessado no processo de criação do livro. A } \\
\text { professora elucida o aluno. }\end{array}$ \\
\hline $1817-1844$ & $\begin{array}{l}\text { Luciana chama a atenção de alguns alunos que não estão se } \\
\text { comportando devidamente. }\end{array}$ \\
\hline $1845-1981$ & $\begin{array}{l}\text { A professora recupera juntamente com os alunos o que já foi } \\
\text { lido da história. Além de recuperar informações importantes, } \\
\text { Luciana promove uma reflexão sobre o que foi lido, auxiliando os } \\
\text { alunos a interpretarem algumas expressões utilizadas pelo autor: } \\
\text { macaquinhos no sótão, pés de vento etc. }\end{array}$ \\
\hline
\end{tabular}

Conforme descrito no primeiro momento do Quadro 2B, Luciana inicia a atividade dizendo que já começaram a história na aula passada; diz o nome do autor (Ziraldo), pois não havia feito isso anteriormente (linhas 1757-1775). João Pedro demonstra interesse no processo de criação do livro ao perguntar: "como/ ele ((o autor)) conseguiu fazer/ tantas/ páginas?" (Quadro 3B, linhas 1794-1797). O aluno parece admirado com a capacidade de escrever do autor e a professora conta-lhe então, que Ziraldo dedica-se inteiramente a escrever histórias para crianças, usando sua imaginação e criatividade (Quadro 3B, linhas 1781-1788;

Educação \& Realidade, Porto Alegre, v. 38, n. 4, p. 1303-1326, out./dez. 2013. 1313 Disponível em: <http://www.ufrgs.br/edu_realidade> 
1798-1802). Acrescenta, ainda, que o autor não escreve tudo de uma só vez (Quadro 3B, linhas 1804-1809), ao que Henrique completa: “ele faz/ uma página/ de cada vez" (Quadro 3B, linhas 1810-1812).

A apresentação do livro e as dúvidas de João Pedro podem ser vistas no quadro a seguir:

Quadro 3B - Transcrição em Sequência Discursiva (Linhas 1757-

1775 [...]; 1777-1790 [...]; 1794-1802 [...]; 1804-1816)

\begin{tabular}{|l|l|l|}
\hline Linhas & Participantes & Comentários \\
\hline 1757 & Profa: posso começar? & Professora ini- \\
1758 & Alunos: pode & cia a atividade \\
1759 & Profa: na semana passada de história. \\
1760 & na sexta-feira & Os alunos estão \\
$1761-1762$ & nós começamos/ a ler & sentados no chão, \\
1763 & Alunos: o menino & poltados para a \\
$1764-1765$ & Profa.: o menino/ maluquinho aten- \\
$1766-1768$ & quem/ que é o autor/ desse livro & tos a ela.A profes- \\
1769 & eu contei? & sora está sentada \\
1770 & Alunos: não & em uma cadeira. \\
$1771-1774$ & Profa.: pois é/ um moço/ que se chama/ ZIRALDO Eduarda \\
1775 & Matheus A.: (eu sabia) & continua separa- \\
& da do grupo. \\
$1777-1780$ & João Pedro: como ele fez/ TANTAS/ histórias/ assim? \\
$1781-1782$ & Profa.: porque ele/ é um escritor & Alunoseprofesso- \\
$1783-1785$ & ele trabalha/ a vida dele/ TODINHA & ra conversam so- \\
$1786-1788$ & é escrevendo/ história/ pra crianças & bre o processo de \\
1789 & João Pedro: não & criação dolivro. \\
1790 & eu tô falando(...) & \\
$1794-1797$ & COMO/ ele conseguiu fazer/ tantas/ PÁginas & \\
1798 & Profa.: ah:: & \\
1799 & imaginação... & \\
1800 & imaginação & \\
1801 & criatividade & \\
1802 & não é? & \\
1804 & Profa.: e ele não faz & \\
$1805-1806$ & TUDO/ de uma vez só & \\
1807 & João Pedro & \\
1808 & tá? & \\
1809 & ele(...) & \\
$1810-1812$ & Henrique: ele faz/ uma página/ de cada vez & \\
1813 & Profa.: é: & \\
1814 & isso mesmo & \\
$1815-1816$ & João Pedro: e ele desenha/ bonito & \\
& & \\
& & \\
&
\end{tabular}

Dando continuidade, Luciana conversa com os alunos, recuperando o que foi lido na aula anterior, primeiramente explorando a ilustração da capa e logo depois utilizando o corpo do texto e as ilustrações (a professora expõe o livro aberto enquanto faz o reconto). Como as informações visuais, presentes na capa do livro, não dão conta de toda a personalidade do Maluquinho, este passa a ser caracterizado pelos alunos e pela professora através das informações contidas no texto. Dessa forma, outros mediadores semióticos são trabalhados pelo grupo ao relacionarem as informações da capa ao conteúdo do livro. $\mathrm{O}$ acesso às ilustrações também auxilia alunos e professora a resgatarem a história lida.

1314 Educação \& Realidade, Porto Alegre, v. 38, n. 4, p. 1303-1326, out./dez. 2013. Disponível em: <http://www.ufrgs.br/edu_realidade> 
Nesse momento, professora e alunos exploram alguns dos elementos que compõem o livro: os paratextos (nesse caso, o nome do autor); o número de páginas e o processo de elaboração do livro; e o projeto gráfico (capa, ilustrações). Tais informações são fundamentais no processo de escolha do livro. Segundo Paiva e Rodrigues (2008),

Na biblioteca, durante a escolha do livro a ser lido em casa, é imprescindível que os alunos façam uma leitura atenta, em especial, da capa e quarta capa do livro, já que não é possível ler a história completa no pouco tempo que eles possuem. Também é importante que saibam identificar autores e/ou ilustradores conhecidos, ou leiam, quando houver, o pequeno resumo da história, ou consigam relacionar as ilustrações que podem estar presentes tanto na capa, quanto na quarta capa com o título da obra. A familiaridade com elementos do projeto gráfico-editorial de um livro de literatura pode auxiliar os alunos nas suas escolhas, que deixam de ser aleatórias, para que passem a considerar não apenas o tamanho do livro, da letra ou o colorido das imagens, mas a autoria do texto e das ilustrações, identificando propostas editoriais, entre outros aspectos (Paiva; Rodrigues, 2008, p. 113-114).

Também é interessante notar que, ao conversar com as crianças sobre a ilustração da capa, Luciana leva os alunos a relacionarem seu próprio universo ao universo ficcional a que o personagem pertence ao perguntar se eles já vestiram roupas dos pais, assim como o Menino Maluquinho (Quadro 3C, linhas 1871-1883).

Além disso, a professora aproveita o momento do reconto para explorar algumas expressões utilizadas pelo autor para caracterizar o personagem como uma criança que tem: "fogo no rabo", "olho maior que a barriga”, "ventos nos pés”, "macaquinhos no sótão” etc. Pergunta aos alunos o que essas expressões significam (Quadro 3C, linhas 1927-1929; 1935-1943), incentivando-os a produzirem inferências sobre o texto. A professora pergunta: "mas o quê/ que é isso?/ macaquinhos na[...]/ no sótão?/ O que será/ que ele tem/ na cabeça/ de verdade?” (Quadro 3C, linhas 1936-1943). Joyce considera o sentido literal da expressão: "macaco" (Quadro 3C, linha 1944) e a professora sugere: “muitas ideias?” (Quadro 3C, linha 1945). Igor diz “não” (Quadro 3C, linha 1946), mas João Pedro concorda com a professora: "muitas ideias/ pra gente fazer/ as coisas/ o cérebro" (Quadro 3C, linhas 1947-1950). Em alguns momentos, a própria professora explica o sentido de tais expressões, dando pistas aos alunos de como as metáforas usadas por Ziraldo, aqui vistas como mediadoras semióticas, podem ser compreendidas, auxiliandoos a compreender a história do Menino Maluquinho, como se pode ver na seguinte fala de Luciana: "vento/ nos pés/ porque ele/só anda correndo/ não é?” (Quadro 3C, linhas 1963-1967).

$\mathrm{O}$ quadro a seguir mostra como professora e alunos retomam a história explorando texto e ilustrações enquanto constroem coletivamente sentidos para o texto lido:

Educação \& Realidade, Porto Alegre, v. 38, n. 4, p. 1303-1326, out./dez. 2013.1315 Disponível em: <http://www.ufrgs.br/edu_realidade> 
Aprendizagem e Desenvolvimento de Crianças de Seis Anos na Roda de História

Quadro 3C - Transcrição em Sequência Discursiva (Linhas 18451846 [...]; 1848-1917 [...]; 1923-1924 [...]; 1927-1929 [...]; 1932-1967)

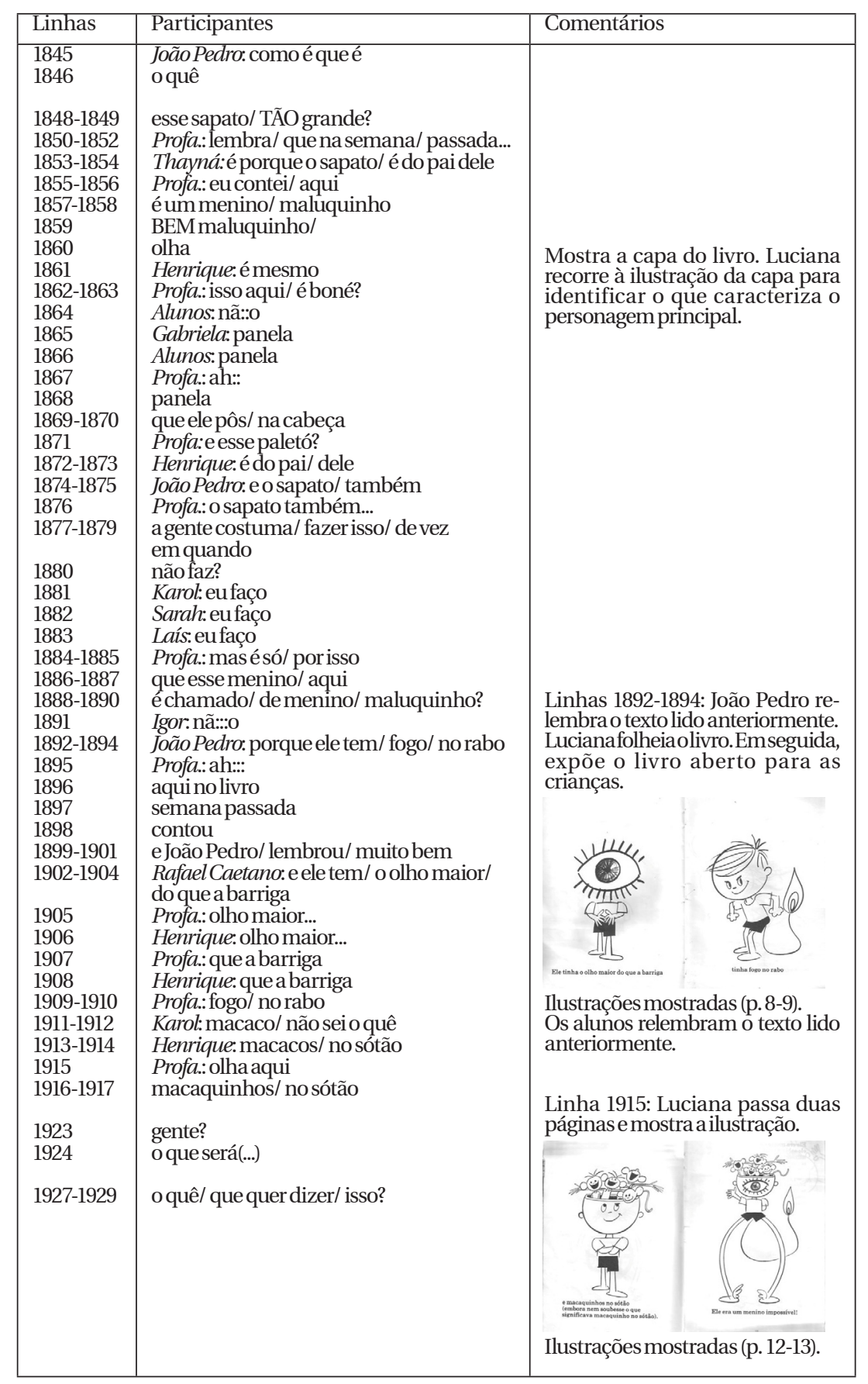

1316 Educação \& Realidade, Porto Alegre, v. 38, n. 4, p. 1303-1326, out./dez. 2013. Disponível em: <http://www.ufrgs.br/edu_realidade> 


\begin{tabular}{|c|c|c|}
\hline $\begin{array}{l}1932-1934 \\
1935 \\
1936-1937 \\
1938 \\
1939 \\
1940-1942 \\
1943 \\
1944 \\
1945 \\
1946 \\
1947 \\
1948-1949 \\
1950 \\
1951 \\
1952 \\
1953-1954 \\
1955-1958 \\
1959 \\
1960-1961 \\
1962 \\
1963-1964 \\
1965-1966 \\
1967\end{array}$ & $\begin{array}{l}\text { Henrique: porque ele tem/macaquinho/ } \\
\text { na cabeça } \\
\text { Profa.: poisé... } \\
\text { maso quê/ que éisso? } \\
\text { macaquinhos na(...) } \\
\text { no sótão? } \\
\text { o que será/ que ele tem/ na cabeça? } \\
\text { de verdade? } \\
\text { Joyce: macaco } \\
\text { Profa.: muitasideias? } \\
\text { Igor:não } \\
\text { JoãoPedro: muitas ideias } \\
\text { pra gentefazer/ as coisas } \\
\text { o cérebro } \\
\text { Profa.:é... } \\
\text { aquiolha } \\
\text { nós vimos/ semana passada } \\
\text { que ele tem/ a perna/ que dá pra abraçar/ } \\
\text { o mundo } \\
\text { e tem...? } \\
\text { Alunos: ventos/ nos pé } \\
\text { Profa:: ah: } \\
\text { vento/ nos pés } \\
\text { porque ele/só anda correndo } \\
\text { nãoé? }\end{array}$ & Voltaà página anterior. \\
\hline
\end{tabular}

Continuando a leitura do livro O Menino Maluquinho, é importante ressaltar que, por várias vezes, Luciana precisa interromper a atividade para organizar novamente a roda (Quadro 2B, linhas 1817-1844; Quadro 2C, linhas 2060-2128; Quadro 2E, linhas 2593-2610 e linhas 2999-3031), pedindo aos alunos que façam silêncio, que fiquem sentados em seus lugares, quietos para não incomodarem os colegas etc, o que não a impede de dar continuidade à atividade como se pode ver no quadro $2 \mathrm{C}$ a seguir:

Quadro 2C - Síntese Descritiva da Roda de História

\begin{tabular}{|l|l|}
\hline Linhas & Descrição das interações entre os participantes \\
\hline $1982-2059$ & $\begin{array}{l}\text { A professora recupera, lendo ou contando com suas próprias } \\
\text { palavras, mais alguns trechos da história. Esclarece os trechos } \\
\text { lidos, apresentando o significado de algumas palavras e o sentido } \\
\text { que adquirem no texto }\end{array}$ \\
\hline $2060-2128$ & $\begin{array}{l}\text { A professora organiza novamente a roda, chamando a atenção de } \\
\text { alguns alunos. Luciana chama Maria Eduarda que até então tinha } \\
\text { permanecido sentada em sua carteira para ir para a roda. A aluna } \\
\text { diz estar com saudades de sua mãe e a professora insiste para que } \\
\text { a aluna fique perto dela e que logo estará na hora de ir embora. } \\
\text { Maria Eduarda integra-se ao grupo de crianças assentados no chão } \\
\text { perto da professora. }\end{array}$ \\
\hline $2129-2149$ & $\begin{array}{l}\text { A professora relê mais um trecho da história, o último lido na aula } \\
\text { anterior. }\end{array}$ \\
\hline
\end{tabular}

Conforme o Quadro 2C, Luciana continua recuperando a história juntamente com os alunos (linhas 1982-2059; 2129-2149), prática fun-

Educação \& Realidade, Porto Alegre, v. 38, n. 4, p. 1303-1326, out./dez. 2013. 1317

Disponível em: <http://www.ufrgs.br/edu_realidade> 
Aprendizagem e Desenvolvimento de Crianças de Seis Anos na Roda de História

damental quando se realiza a leitura em partes, pois garante a continuidade da leitura. Para tanto, a professora mostra as ilustrações, faz perguntas, comentários ou explica o significado de alguma palavra ou termo, conta a história com suas próprias palavras e lê alguns trechos, utilizando, dessa forma, diferentes estratégias de leitura, diferentes mediadores semióticos.

É interessante notar a importância da ilustração na recuperação da história. Segundo Bajard (2007, p. 55) o livro infantil se tornou bilíngue, ou seja, a narrativa emerge tanto do texto gráfico quanto das imagens. Ao ler e expor as ilustrações o/a professor/a vincula texto e imagem, dando acesso completo à obra. Além do mais, as imagens cativam profundamente as crianças, estimulando-lhes a atenção, a imaginação e a memória. Os alunos resgatam o texto principalmente ao ver as ilustrações expostas pela professora.

Luciana também aproveita este momento para orientar os alunos na interpretação do texto, destacando os recursos expressivos utilizados pelo autor ao esclarecer o significado e o sentido das expressões utilizadas por ele para caracterizar o personagem, como na passagem "Pra uns/ era um uirapuru ((lendo)). Uirapuru/ é um pássaro/ do Brasil/ um pássaro/ brasileiro/ que canta/ muito bonito./ Pra outros/ era/ um saci ((lendo))./ Saci Pererê./ De tão levado/ que ele era/ as pessoas achavam/ que ele era/ um saci” (Quadro 3D, linhas 2014-2031). Os alunos participam ativamente, resgatando trechos da história e fazendo comentários, conforme o Quadro 3D (linhas 2012-2013; 2037-2059) a seguir:

Quadro 3D - Transcrição em Sequência Discursiva (Linhas 20142050 [...]; 2061-2073 [...]; 2077-2079)

\begin{tabular}{|c|c|c|}
\hline Linhas & Participantes & Comentários \\
\hline $2014-2015$ & Profa:: prauns/era um uirapuru & Os trechos em itálico repre- \\
\hline $2016-2018$ & uirapuru/ éum pássaro/do Brasil & sentam a leitura integral do \\
\hline $2019-2022$ & $\begin{array}{l}\text { um pássaro/ brasileiro/ que canta/ muito } \\
\text { bonito }\end{array}$ & texto. \\
\hline 2023-2025 & praoutros/era/umsaci & \\
\hline 2026 & sacipererê & \\
\hline 2027-2028 & de tã̃olevado/ que ele era & \\
\hline 2029-2031 & as pessoas achavam/ que ele era/ um saci & \\
\hline 2032 & ah::: & \\
\hline 2033-2034 & mas vamolembrar/ aqui & Expõeaosalunosolivroaberto. \\
\hline 2035-2036 & mas da turma dele/ ele era o quê? & \\
\hline 2037 & Gabriela:pequeno & \\
\hline 2038 & Henrique. mais pequeno & Relembra o texto utilizando \\
\hline 2039 & mais sabidinho & suas próprias palavras ${ }^{6}$. \\
\hline 2040 & mais maluquinho & \\
\hline 2041 & Profa.: maisami(...) & \\
\hline 2042 & mais... & \\
\hline 2043 & Gabriel:amigão & Relembra o texto utilizando \\
\hline 2044 & Profa: pequenininho & suas próprias palavras? \\
\hline 2045 & mas ele era um? & \\
\hline 2046 & Gabriel: amigão & \\
\hline 2047 & Profa:: amigã̃o & Expressão utilizada pelo autor. \\
\hline 2048-2049 & um companheirão/ nãoé? & $\mathrm{O}$ aluno expressa sua opinião \\
\hline 2050 & Rafael Caetano: e um doidão & sobre o personagem. \\
\hline
\end{tabular}

1318 Educação \& Realidade, Porto Alegre, v. 38, n. 4, p. 1303-1326, out./dez. 2013 Disponível em: <http://www.ufrgs.br/edu_realidade> 


\begin{tabular}{|c|c|c|}
\hline $\begin{array}{l}2061 \\
2062-2064 \\
2065 \\
2066-2067 \\
2068 \\
2069-2070 \\
2071-2072 \\
2073\end{array}$ & $\begin{array}{l}\text { JoãoPedro: ah:: } \\
\text { eulembro/ que vocêparou/ aí } \\
\text { Profa:: ô Igor? } \\
\text { nós podemos/ continuar? } \\
\text { porque vocêta en(...) } \\
\text { tá encostando muito/ nos coleguinhas } \\
\text { fica mais/ quietinho } \\
\text { Sarah? }\end{array}$ & $\begin{array}{l}\text { Aponta para o livro exposto pela } \\
\text { professora. }\end{array}$ \\
\hline $\begin{array}{l}2077-2078 \\
2079\end{array}$ & $\begin{array}{l}\text { ô/ Maria Eduarda? } \\
\text { vem pra cá }\end{array}$ & $\begin{array}{l}\text { Ilustração mostrada (p. 22-23). } \\
\text { Linhas2077-2079: até o momen- } \\
\text { to, Maria Eduarda permaneceu } \\
\text { sentada em sua carteira, } \\
\text { separada do grupo. }\end{array}$ \\
\hline
\end{tabular}

A atitude de Luciana, ao explicar o sentido das expressões utilizadas no texto, permite aos alunos perceberem que é necessário ir além das palavras escritas e buscar a intenção do autor ao colocá-las de tal forma. Esse movimento é fundamental para que o leitor possa compreender a obra literária e apreciá-la ao máximo.

Dessa forma, podemos perceber que "a prática de compartilhamento de informações, experiências e saberes entre a professora e as crianças e entre as próprias crianças" é fundamental para que os alunos desenvolvam a capacidade de "reconhecer as informações que estão explícitas no texto e estabelecer relações e inferências sobre os elementos subentendidos do texto", atingindo a compreensão, meta principal do ensino da leitura (Dias, 2011, p. 213).

Junto a essas construções coletivas, há que se resolver a situação de isolamento em que Maria Eduarda se colocou, quando ouvia a história de sua própria carteira. Somente muito depois a professora se dá conta disso e a convida para se reunir ao grupo. Fazer parte do grupo, tornar-se um membro desse grupo, também é um processo coletivo e individual de construção de novas identidades de ser aluna. Tornar-se aluna requer ser membro do grupo, sentir-se parte dele e também vir a ser algo que Maria Eduarda ainda não era até bem pouco tempo, antes de entrar para essa escola. Significa o início da luta por novas identidades, a tentativa de superar a divisão e alcançar a totalidade - tornar-se o mesmo eu, que antes era apenas filha e agora se torna filha e aluna. "E, esta identidade não é uma simples igualdade a si mesma, mas "negação - negatividade", porque a identidade humana é alcançada em atividade prática" (Kojève, 1947; 1969, p. 5, 213n apud Packer; Goicochea, 2000, p. 234).

Até o momento, Luciana e as crianças estiveram recuperando a parte do livro já lida na aula anterior, assim como a adesão de todos a esta prática social. Dando continuidade ao evento, professora e alunos iniciam a leitura inédita da história como podemos ver no quadro $2 \mathrm{D}$ a seguir:

Educação \& Realidade, Porto Alegre, v. 38, n. 4, p. 1303-1326, out./dez. 2013.1319 Disponível em: <http://www.ufrgs.br/edu_realidade> 
Aprendizagem e Desenvolvimento de Crianças de Seis Anos na Roda de História

\section{Quadro 2D - Síntese Descritiva da Roda de História}

\begin{tabular}{|l|l|}
\hline Linhas & Descrição das interações entre os participantes \\
\hline $2150-2182$ & $\begin{array}{l}\text { Luciana inicia a leitura inédita da história. Lê uma página e mostra } \\
\text { a ilustração, fazendo comentários sobre a imagem e o texto, } \\
\text { ampliando sua significação. }\end{array}$ \\
\hline $2183-2284$ & $\begin{array}{l}\text { João Pedro, vendo a ilustração, pergunta a respeito da diferença } \\
\text { de letras (tipografia) utilizadas na página. A professora explica a } \\
\text { intenção do autor em utilizar tal recurso gráfico, mas utiliza-se do } \\
\text { próprio universo ficcional para fazer isso. João Pedro questiona se } \\
\text { a personagem é real. A professora responde na forma de perguntas, } \\
\text { permitindo aos alunos tirarem suas próprias conclusôes e } \\
\text { evidenciando o pacto ficcional'. }\end{array}$ \\
\hline $2285-2441$ & $\begin{array}{l}\text { Os alunos aproveitam para perguntar sobre o processo de produção } \\
\text { material do livro: como são feitas as páginas, como elas são } \\
\text { coladas, como é feito o papel, culminando em uma conversa sobre } \\
\text { reciclagem de papel. }\end{array}$ \\
\hline
\end{tabular}

Conforme o Quadro 2D, Luciana mostra a página em que interromperam a leitura na aula anterior. Em seguida, prossegue com a leitura do livro. Após ler uma página, expõe a ilustração e comenta o texto lido. A estratégia de leitura utilizada pela professora, fazendo uso de diversos mediadores semióticos como a alternância da leitura do texto e exposição das imagens, amplia as possibilidades de significação do texto já que, no livro infantil, escrita e imagem compartilham o ato de contar histórias (Fittipaldi, 2008; Bajard, 2007).

Os alunos continuam participando ativamente do momento de leitura. As questões que estes trazem, tornam evidentes os processos de criação (autoria) e de produção material do livro, que se constituem como objetos de curiosidade e de reflexão de todo o grupo. A participação das crianças com suas questões e colocações enriquece o momento da leitura, pois através de suas dúvidas e interesses outros conhecimentos são trazidos à tona tanto pela professora quanto pelos próprios alunos.

Continuando a leitura do livro, alunos e professora constroem e reconstroem a Roda de História, como se vê nos quadros $2 \mathrm{E}$ e $3 \mathrm{E}$ a seguir:

\section{Quadro 2E - Síntese Descritiva da Roda de História}

\begin{tabular}{|l|l|}
\hline Linhas & Descrição das interações entre os participantes \\
\hline $2442-2592$ & $\begin{array}{l}\text { Luciana continua a leitura do livro, mostra as ilustrações, faz } \\
\text { comentários e perguntas aos alunos sobre a história. }\end{array}$ \\
\hline $2593-2610$ & Aprofessora organiza a roda chamando a atenção de algumas alunas. \\
\hline $2611-2998$ & $\begin{array}{l}\text { Luciana retoma a leitura do livro seguindo o mesmo padrão de } \\
\text { leitura. Ao ler um trecho da história pergunta aos alunos o que eles } \\
\text { acham que vai acontecer em seguida, incentivando-os a levantarem } \\
\text { hipóteses sobre a história; os alunos dão suas opiniões e Luciana } \\
\text { retoma a leitura para confirmar ou não as hipóteses das crianças. }\end{array}$ \\
\hline $2999-3031$ & \begin{tabular}{l} 
Luciana interrompe a leitura para organizar novamente a roda. \\
\hline
\end{tabular}
\end{tabular}

1320 Educação \& Realidade, Porto Alegre, v. 38, n. 4, p. 1303-1326, out./dez. 2013. Disponível em: <http://www.ufrgs.br/edu_realidade> 


\begin{tabular}{|l|l|}
\hline $3032-3109$ & A professora retoma a leitura do livro. \\
\hline $3110-3127$ & $\begin{array}{l}\text { Luciana avisa que irá interromper a Roda de história e passará para } \\
\text { a próxima atividade. Continuarão a leitura do livro na próxima aula. }\end{array}$ \\
\hline
\end{tabular}

No primeiro momento descrito no Quadro 2E, Luciana retoma a leitura do Menino Maluquinho. Além de mostrar as ilustrações, faz comentários, produz inferências sobre o texto. Interpreta a fala dos personagens, atribuindo pensamentos a eles: "aí o avô dele/ olha aqui/ o vovô/ do maluquinho/ disse assim/ ó/ meu neto/ é subversivo/ gritou o avô ((lendo))/ O avô achou/ que o maluquinho/ tinha uma bomba/ de verdade/ uma bomba/ pra estourar/ que ia fazer/ BU:::M" (Quadro 3E, linhas 2684-2700). Em seguida, a professora faz pergunta aos alunos, levantando suas hipóteses sobre o desenvolvimento da história: "quem/ quem arrisca a/ a/ a dizer/ que bomba era essa/ que o maluquinho/ levou/ no final/ do ano?" (Quadro 3E, linhas 2711-2719). Os alunos dão opiniões: Henrique: "era uma bomba" (Quadro 3E, linha 2720); João Pedro: "de plástico" (Quadro 3E, linha 2722); Karol: "ele vai repetir/ o ano" (Quadro 3E, linhas 2727-2728). A professora então os convida a voltar ao texto para confirmar (ou não) suas hipóteses: "vamos ver/ se é isso? ele vai repetir/ o ano/ ou se é uma bomba/ que vai explodir/ na casa dele?" (Quadro 3E, linhas 2732-2738). Luciana retoma a leitura e a hipótese de Karol é confirmada, levando a aluna a comentar: "sabia" (Quadro 3E, linha 2815), e a completar mais à frente: "minha mãe me explicou/ quê que é isso" (Quadro 3E, linha 2823-2824). Luciana explica aos alunos que tomar bomba quer dizer repetir o ano, já que as crianças não estão acostumadas com esta expressão (Quadro 3E, linhas 2810-2814 e 28162822), nem vivenciaram essa prática da cultura escolar.

Apesar disso, João Pedro parece não se convencer com a explicação da professora e remete-se a uma bomba de verdade: "é que a bomba/ é uma bomba /que quando a gente/ acende/ na ponta/ aí/ quando a ponta/ já chega ao final/ ela explode" (Quadro 3E, linhas 2831-2839). Luciana demonstra ter compreendido a colocação do aluno e intervém explicitando: "mas não é essa/ bomba/ que o maluquinho/ levou não/ tá?/ ele levou/ foi a bomba/ do boletim/ cheio de zero/ vai repetir de ano" (Quadro 3E, linhas 2841-2851), conforme se pode ver no quadro abaixo: 
Aprendizagem e Desenvolvimento de Crianças de Seis Anos na Roda de História

Quadro 3E - Transcrição em Sequência Discursiva (Linhas 26692675 [...]; 2681-2745 [...]; 2749 [...]; 2786-2851)

\begin{tabular}{|c|c|c|}
\hline Linhas & Participantes & Comentários \\
\hline 2669 & Profa: um dia & Ostrechosemitálicorepre- \\
\hline $2670-2671$ & num fim/deano & sentam a leitura integral \\
\hline $2672-2675$ & $\begin{array}{l}\text { omenino/maluquinho/chegouem casa/com uma } \\
\text { bomba }\end{array}$ & dotexto. \\
\hline 2681 & Profa:: mamãe & \\
\hline $2682-2683$ & tôaí/com umabomba & \\
\hline 2684 & aío avô dele & \\
\hline 2685 & olha aqui & Mostraasilustrações. \\
\hline 2686-2688 & ovovô/ do maluquinho/ disseassim & \\
\hline 2689 & & \\
\hline $2690-2691$ & meuneto/ésubversivo & \\
\hline 2692 & gritouoavô & \\
\hline 2693-2696 & $\begin{array}{l}\text { o avôachou/ que o maluquinho/ tinha umabom- } \\
\text { ba/de verdade }\end{array}$ & \\
\hline $2697-2698$ & umabomba/ pra estourar & \\
\hline $2699-2700$ & queiafazer/ BU:::M & Professora faz um gesto \\
\hline 2701 & Rafael Caetano: uma bomba & com as mãos represen- \\
\hline 2702 & & tando uma bomba explo- \\
\hline 2703 & éumbi & dindo. \\
\hline 2704 & éumbicho & \\
\hline 2705-2706 & minha mãe/ já ouviu & \\
\hline 2707 & ( ) & \\
\hline $2708-2710$ & Laís: deixa eu ver/ ( )/ professora & \\
\hline 2711 & Profa:: quem & \\
\hline 2712-2714 & quemarriscaa/a/ a dizer & \\
\hline 2715-2719 & $\begin{array}{l}\text { que bomba era essa/ que o maluquinho/ levou/ no } \\
\text { final/ do ano? }\end{array}$ & \\
\hline 2720 & Henrique. era umabomba & Karollevanta o dedo. \\
\hline 2721 & Profa: quebomba? & Os alunos dão suas opi- \\
\hline 2722 & JoãoPedro: de plástico & niões. \\
\hline $2723-2724$ & Profa.: umabomba/ que explode? & \\
\hline 2725 & Karol:eusei & \\
\hline 2726 & elevai/ & \\
\hline $2727-2728$ & elevai repetir/ o ano & \\
\hline 2729 & elevairepetir & \\
\hline 2730 & Profa.: ah:: & \\
\hline 2731 & Karol: oano & \\
\hline 2732-2733 & Profa: vamos ver/ se éisso? & \\
\hline 2734-2735 & elevai repetir/ o ano? & \\
\hline $2736-2738$ & ou seéumabomba/ que vai explodir/ na casa dele? & \\
\hline 2739-2740 & oavôdele/ táachando/ & \\
\hline 2741-2742 & queéumabomba/ quevai explodir & \\
\hline $2743-2745$ & porque tá chamando/ o neto aqui/ de subversivo & \\
\hline 2749 & olhasó & Passa a página. \\
\hline $2786-2787$ & Profa.: masaí/omenino explicou & \\
\hline $2788-2790$ & abombal jáexplodiu/gente & \\
\hline 2791-2792 & lá:::/nocolégio & \\
\hline 2793-2794 & essemenino/émaluquinho & \\
\hline 2795-2796 & falou opai/aliviado & \\
\hline 2797-2798 & e foiconferir/ oboletim & \\
\hline 2799-2800 & aíomenino mostrou/ o boletim & \\
\hline 2801 & olha aqui & A professora refere-se à \\
\hline 2802-2803 & Karol: ele tomou bomba/ e vai repetir o ano & imagem abaixo (p. 36). \\
\hline 2804-2806 & Profa:: o boletim/ todo cheio/ de zero & Luciana expõe o livro \\
\hline 2807 & olhaaí & aberto aos alunos. \\
\hline 2808-2809 & Karol:vai repetir/ o ano & \\
\hline
\end{tabular}

1322 Educação \& Realidade, Porto Alegre, v. 38, n. 4, p. 1303-1326, out./dez. 2013.

Disponível em: <http://www.ufrgs.br/edu_realidade> 


\begin{tabular}{|c|c|c|}
\hline 2810 & Profa:: elefoitão maluquinho & $T$ \\
\hline 2811 & mas tão maluquinho & $\begin{array}{l}\text { Mas aio menino explicout } \\
\text { Maton }\end{array}$ \\
\hline 2812 & naquele ano & 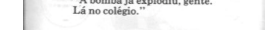 \\
\hline $2813-2814$ & que ele vai ter/ que repetir de ano & \\
\hline 2815 & Karol: sabia & \\
\hline $2816-2817$ & Profa:: vai fazer o primeiro ano/ de novo & \\
\hline $2818-2819$ & isso queé/ tomarbomba & \\
\hline $2820-2822$ & isso que é/ levar umabomba/ pra casa & \\
\hline 2823 & Karol:minhamãeme explicou & 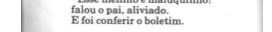 \\
\hline 2824 & quêqueéisso & \\
\hline 2825 & Rafael S.: tomar umabomba & \\
\hline $2826-2827$ & éque não vai/ passar deano? & Linha2815:aalunaKarol \\
\hline 2828 & Profa:é é & confirma suahipótese. \\
\hline $2829-2830$ & quemnãovai/ passar de ano & \\
\hline 2831 & JoãoPedro:équeabomba & \\
\hline 2832 & éumabomba & \\
\hline 2833-2835 & que quando a gente/ acende/ na ponta & \\
\hline 2836-2838 & aí/ quando a ponta/já chega ao final & \\
\hline 2839 & ela explode & \\
\hline 2840 & Profa::é & \\
\hline $2841-2844$ & $\begin{array}{l}\text { mas nãoé essa/ bomba/ que o maluquinho/ levou } \\
\text { não }\end{array}$ & \\
\hline 2845 & & \\
\hline 2846-2848 & elelevou/foi abomba/do boletim & \\
\hline 2849 & cheio de zero & \\
\hline 2850 & etomoubomba & \\
\hline 2851 & vai repetir deano & \\
\hline
\end{tabular}

Ao ler a história para as crianças, a professora fornece aos alunos mecanismos de leitura e de interpretação que costumam ser acionados pelo leitor ao ler um texto: antecipação, elaboração e averiguação de hipóteses, inferenciação, interpretação. Dessa forma, a professora constitui-se como modelo de leitor para as crianças. Segundo Batista et al. (2005, p. 69), "quando o professor lê em voz alta e comenta ou discute com seus alunos os conteúdos e usos dos textos lidos, está contribuindo para o desenvolvimento da capacidade de compreensão".

Assim, a partir da análise do mapa de eventos e das sequências discursivas da sala de aula pesquisada foi possível observar como se deu a atividade proposta e os resultados produzidos. Identificamos as capacidades de leitura que foram sendo construídas pela professora e pelos alunos ao longo das interações estabelecidas entre os participantes e com o objeto livro. Entre elas, destacam-se:

- A contextualização do texto a ser lido, em que a professora e os alunos levantaram questões e conhecimentos sobre autoria e produção do livro.

- O uso de conhecimentos prévios pelos alunos, que relacionaram seus conhecimentos de mundo com os sentidos do texto;

- O levantamento de hipóteses sobre o texto ainda a ser lido, feito pelos alunos a partir do estímulo da professora;

- A produção de inferências, a partir da exploração cuidadosa dos implícitos do texto, ampliando as significações construídas e os conhecimentos de mundo dos membros do grupo.

- A comparação de informações do texto lido com as de outros textos e com o conhecimento de mundo que possuíam;

Educação \& Realidade, Porto Alegre, v. 38, n. 4, p. 1303-1326, out./dez. 2013.1323

Disponível em: <http://www.ufrgs.br/edu_realidade> 
Aprendizagem e Desenvolvimento de Crianças de Seis Anos na Roda de História

- A percepção de outras linguagens como elementos constitutivos dos sentidos dos textos e não somente da linguagem verbal escrita;

- A apreciação estética e/ou afetiva da obra, levando os alunos a manifestarem suas opiniões a respeito do livro e seu autor.

Além disso, o uso de mediadores semióticos diversificados propiciou o enriquecimento do vocabulário das crianças, permitiu que refletissem sobre o processo de produção do livro, agregando conhecimentos relacionados ao universo literário, e que desenvolvessem comportamentos e atitudes necessários à escuta e à leitura de textos.

Finalizando a Roda de História, a professora interrompe a leitura e avisa que irão continuar na próxima aula, entretanto, devido às limitações deste texto, não prosseguiremos com esta análise. Cabe ressaltar, porém, que em nosso banco de dados constam duas outras aulas do ano de 2006 em que a Roda de História foi trabalhada por Luciana: no dia 12/05/2006 e no dia 23/05/2006. Nessas aulas, a dinâmica adotada pela professora mostrou-se um pouco diferente: ela leu o livro e somente ao final da leitura expôs as ilustrações, retomando a história através das imagens. Os alunos participaram retomando a história juntamente com a professora ou fazendo comentários a respeito das ilustrações.

\section{Considerações Finais}

Buscamos, ao longo desse texto, refletir sobre as possibilidades de aprendizagem e desenvolvimento mental e cultural construídos na prática de leitura oral feita pelo/a professor/a em sala de aula com crianças de seis anos de idade, tendo como referência as questões: como, para que, com quem, quando, sob quais condições e com que resultados se lê o texto literário na sala de aula.

A partir da análise das interações produzidas pelos participantes, vimos que, na sala de aula pesquisada, o livro de literatura se configura como objeto a ser apreciado e pressupõe uma relação mais livre com a leitura, levando alunos e professora a explorarem outros espaços e novas configurações da sala de aula. A leitura oral feita pela professora possibilitou aos alunos ativarem conhecimentos prévios, estabelecerem relações entre o texto lido e outros textos e a manifestarem suas opiniões, dúvidas e curiosidades. Dessa forma, os membros do grupo foram convidados ao diálogo, à troca de conhecimentos e de experiências, se constituindo como sujeitos que participam e criam cultura.

Além disso, o contato com o livro de literatura em sua integralidade permitiu que os participantes refletissem sobre ele enquanto objeto complexo, portador de várias linguagens e múltiplos aspectos, levando à apropriação de conhecimentos relacionados ao universo literário fundamentais na formação do leitor crítico.

Ao estimular a participação interativa dos alunos e a construção coletiva de sentidos para o texto lido, respeitando a abertura da obra literária às diferentes leituras produzidas pela subjetividade de seus

1324 Educação \& Realidade, Porto Alegre, v. 38, n. 4, p. 1303-1326, out./dez. 2013. Disponível em: <http://www.ufrgs.br/edu_realidade> 
leitores, a Roda de História propiciou não apenas a aquisição de capacidades de leitura, mas também a formação de múltiplas identidades das crianças, que construíram juntamente com a professora, de forma mediada e coletivamente, oportunidades de exercitarem suas imaginações, levando-as à compreensão simbólica do mundo que as rodeia, ou seja, a oportunidades significativas de aprendizagem e desenvolvimento mental e cultural.

Recebido em 11 de maio de 2012 Aprovado em 04 de janeiro de 2013

\section{Notas}

1 A sala de aula de alfabetização de crianças está localizada no Centro Pedagógico da UFMG. A sala de aula de alfabetização de adultos é de uma escola da Rede Municipal de Ensino de Belo Horizonte, Escola Municipal Honorina Rabelo.

2 Green, J.; Franquiz, M.; Dixon, C. The Myth of the Objective Transcript: transcribing as a situated act. TESOL Quarterly, n. 31, v. 1, p. 172-176, 1999.

3 Este projeto constitui-se como uma das atividades desenvolvidas pelo grupo ProNoturno/FaE/UFMG.

4 Os nomes da escola, da professora e dos alunos serão mantidos, devido à permissão concedida pelos responsáveis no termo de consentimento livre e esclarecido registrado no Comitê de Ética em Pesquisa da UFMG.

5 O tempo de duração anunciado não representa o tempo de duração total do evento, apenas de uma pequena parte que foi capturada pela gravação.

6 Texto: "Na turma em que/ ele andava/ ele era/ o menorzinho/ o mais espertinho/ o mais bonitinho/ o mais alegrinho/ o mais/ maluquinho" (p. 20).

7 Texto: "Era tantas coisas/ terminadas em inho/ que os colegas não entendiam/ como é que ele podia ser/ um companheirão" (p. 22).

8 A análise desta interação será feita de maneira mais detalhada em outro artigo.

\section{Referências}

BAJARD, Élie. Da Escuta de Textos à Leitura. São Paulo: Cortez, 2007.

BATISTA, Antônio Augusto Gomes et al. Capacidades da Alfabetização. Coleção Instrumentos da Alfabetização. V. 2. Belo Horizonte: Ceale/FaE/UFMG, 2005.

COSSON, Rildo. Letramento Literário: teoria e prática. São Paulo: Contexto, 2006.

DIAS, Maíra Tomayno de Melo. O Papel da Linguagem em Uso na Sala de Aula no Processo de Apropriação da Leitura de Crianças e Jovens e Adultos. 2011. Dissertação (Mestrado em Educação) - Programa de Pós-Graduação em Educação, Faculdade de Educação, Universidade Federal de Minas Gerais, Belo Horizonte, 2011.

EVANGELISTA, Aracy. Diversidade na Recepção Estética. In: PAIVA, Aparecida; EVANGELISTA, Aracy; PAULINO, Graça; VERSIANI, Zélia (Org.). No Fim do Século: a diversidade - o jogo do livro infantil e juvenil. Belo Horizonte: Autêntica, 2000. P. 109-120.

FITTIPALDI, Ciça. O que É uma Imagem Narrativa? In: OLIVEIRA, Ieda de (Org.). O que é Qualidade em Ilustração no Livro Infantil e Juvenil: com a palavra, o ilustrador. São Paulo: DCL, 2008. P. 93-121.

Educação \& Realidade, Porto Alegre, v. 38, n. 4, p. 1303-1326, out./dez. 2013.1325

Disponível em: <http://www.ufrgs.br/edu_realidade> 
Aprendizagem e Desenvolvimento de Crianças de Seis Anos na Roda de História

GOMES, Maria de Fátima Cardoso. Incluindo Diferentes Alunos nas Salas de Aula de Alfabetização de Crianças e Adultos: semelhanças e diferenças. Projeto de Pesquisa Recém-Doutor, Faculdade de Educação, UFMG, Belo Horizonte 2005.

GOMES, Maria de Fátima Cardoso; DIAS, Maíra Tomayno de Melo; SILVA, Luciana Prazeres da. O Registro da Rotina do Dia e a Construção de Oportunidades de Aprendizagem da Escrita. In: CASTANHEIRA, Maria Lúcia; MACIEL, Francisca Izabel Pereira; MARTINS, Raquel Márcia Fontes (Org.). Alfabetização e Letramento na Sala de Aula. Belo Horizonte: Autêntica/ Editora Ceale, 2008. P. 59-74.

MORAIS, José. A Arte de Ler. São Paulo: Editora UNESP, 1996.

PACKER, Martin J.; GOICOCHEA, Jessie. Sociocultural and Constructivist Theories of Learning: ontology, not just epistemology. Educational Psychologist, NY, Lawrence Erlbaum Associates, v. 35, n. 4, p. 227-241, 2000.

PAIVA, Aparecida; PAULINO, Graça; PASSOS, Marta. Literatura e Leitura Literária na Formação Escolar: caderno do professor. Belo Horizonte: Ceale, 2006.

PAIVA, Aparecida; RODRIGUES, Paula Cristina de Almeida. Letramento Literário na Sala de Aula: desafios e possibilidades. In: CASTANHEIRA, Maria Lúcia; MACIEL, Francisca Izabel Pereira; MARTINS, Raquel Márcia Fontes (Org.). Alfabetização e Letramento na Sala de Aula. Belo Horizonte: Autêntica, Editora Ceale, 2008. P. 103-119.

PINO, Angel. O Conceito de Mediação Semiótica em Vygotsky e seu Papel na Explicação do Psiquismo Humano. 2. ed., Campinas: Papirus, 1991. (Caderno CEDES; n. 24)

PRESTES, Zoia R. Quando não É a Mesma Coisa: traduções de Lev Semionovitch Vigotski no Brasil. Campinas, SP: Autores Associados, 2012.

MONTEIRO, S. M.; BAPTISTA, M. C. Dimensões da Proposta Pedagógica para o Ensino da Linguagem Escrita em Classes de Seis Anos. In: MACIEL, F. I. P.; BAPTISTA, M. C.; MONTEIRO, S. M. (Org.). A Criança de 6 anos, a Linguagem Escrita e o Ensino Fundamental de Nove Anos: orientações para o trabalho com a linguagem escrita em turmas de crianças de seis anos de idade. Belo Horizonte: UFMG/FaE/CEALE, 2009. P. 29-67.

VYGOTSKY, Lev S. Pensamiento y palabra. In: VYGOTSKY, Lev S. Obras Escogidas. Lisboa: Aprendizaje/ Visor, 1993 (original, 1934). Volume 2, p. 287-348.

Tatyane Andrade Almeida foi bolsista do ProNoturno, foi Assistente de Pesquisa do Grupo de Estudos e Pesquisas em Psicologia Histórico-cultural na Sala de Aula (GEPSA). Graduou-se em Pedagogia na FaE/UFMG.

E-mail: tatyaneandrade2008@gmail.com

Maria de Fátima Cardoso Gomes é professora Doutora de Psicologia da Educação da FaE/UFMG, graduação e pós-graduação. Coordenadora do Grupo de Estudos e Pesquisas em Psicologia Histórico-Cultural na Sala de Aula, pesquisadora do CEALE/FaE/UFMG.

E-mail:mafacg@gmail.com

Sara Mourão Monteiro é professora Doutora da FaE/UFMG, pesquisadora do CEALE. Coordenadora do ProNoturno da FaE/UFMG.

E-mail:mourao.sara@gmail.com

1326 Educação \& Realidade, Porto Alegre, v. 38, n. 4, p. 1303-1326, out./dez. 2013 Disponível em: <http://www.ufrgs.br/edu_realidade> 